\title{
SHORT-COMMUNICATION
}

\section{Genetic distinctiveness of the Waikawa Island mouse population indicates low rate of dispersal from mainland New Zealand}

\author{
Ellie Bradley, Steven A. Trewick and Mary Morgan-Richards* \\ Ecology Group, Institute of Agriculture and Environment, Massey University, Private Bag 11 222, Palmerston North, \\ New Zealand \\ *Author for correspondence (Email: m.morgan-richards@massey.ac.nz)
}

Published online: 7 February 2017

\begin{abstract}
In New Zealand, mice in reserves can complicate the control of mammalian predator invasion by masking scent and eating baits. Eradicating mice allows predator invasions to be more readily detected and managed, but removal of mice is only feasible if recolonisation is rare. We used genetics and morphology to assess whether the mouse population on Waikawa Island was isolated from the mainland population. A sample of mitochondrial DNA sequences revealed that at least four female mice must have founded the Waikawa population, but that gene flow between island and mainland mice is limited. Although no variation in DNA sequences of exon 1 of the nuclear gene vitamin K 2,3-epoxide reductase subcomponent 1 was detected, the common allele is not associated with resistance to anticoagulant rodenticides such as warfarin. Body size comparisons revealed the island population as distinct, possibly due to age structure differences. We infer low levels of successful dispersal between the mainland and Waikawa Island mouse populations and suggest eradication might be sustainable in the long-term if protection against rodent invasion is maintained.
\end{abstract}

Keywords: D-loop; gene flow; mitochondrial DNA; Mus musculus domesticus; vitamin K 2,3-epoxide reductase

\section{Introduction}

Colonisation of islands often involves a small founding population of a species with a fraction of the allelic diversity of the source population (Charlesworth 2009; Excoffier et al. 2009). Over time, if the population remains isolated, genetic drift further reduces allelic variation and new alleles may arise through mutation and recombination (but only if more than one allele is present in the population; Charlesworth 2009). Therefore, island populations tend to become genetically distinct from their source population; however, if gene flow continues between the two populations, they will remain homogenous and genetic diversity in the island population will be maintained (Slatkin 1987). Thus, we can use the genetic composition of island and mainland populations to suggest the origin of the island population, as well as the degree to which the populations interact (Avise 2000; Bloomquist et al. 2010; Robins et al. 2016). Assessments can underestimate the rate of dispersal because existing populations lower the success rate of new individuals establishing (Fraser et al. 2015), but until we detect population differentiation we will not know if the populations are potentially isolated (Lowe et al. 2004). Identifying the source population and the frequency of dispersal of an invasive species, such as Mus musculus, may be key to developing better control methods and efficient investment in realistic long-term eradication plans (Sakai et al. 2001; MacKay et al. 2013).

Waikawa Island (also known as Portland) is a 120 ha, privately owned island near the south-east coast of Mahia Peninsula, eastern North Island, New Zealand. Waikawa Island plays a vital role in the recovery of the endangered New Zealand shore plover (Thinornis novaeseelandiae; red list category: Endangered D; Department of Conservation
(DOC) status: nationally critical). There are approximately 60 breeding pairs of $T$. novaeseelandiae remaining in the wild, with only three known breeding sites (Rangatira in the Chatham Islands, Motutapu in the Hauraki Gulf, and Waikawa Island; Dowding \& O'Connor 2013). Waikawa Island is home to other rare birds - New Zealand dotterel (Charadrius obscurus; nationally vulnerable) and white-faced storm petrel (Pelagodroma marina; relic) - as well as two New Zealand endemic lizards, the common skink (Oligosoma polychroma) and common gecko (Woodworthia maculata).

DOC manages the Waikawa Island shore plover recovery programme and was recently challenged by rat incursions on this formerly rat free island. It is thought that individual rats (Rattus spp.) swim $\sim 1 \mathrm{~km}$ between Mahia Peninsula and Waikawa Island (Tabak et al. 2015; H. Jonas, DOC, pers. comm.). The presence of rats became apparent during the shore plover breeding season when dead chicks bearing signs of rodent predation were found. In 2014, efforts to eliminate a rat were hindered by the overwhelming abundance of mice on the island competing for baits and masking smells used by predator-detection dogs (Russell et al. 2008). Removal of mice from Waikawa Island would help future-proof the island by making any subsequent rodent invasion easier to detect and eradicate, and also could increase resources available to native species. For example, lizard activity has been found to increase due to reduced competition and reduced predation of juvenile lizards when mouse density is suppressed (Newman 1994; Wedding 2007).

Although rats probably swim to Waikawa Island, it is thought that mice can only reach the island as stowaways. People and livestock regularly travel to the island by boat or barge from the Mahia coast and this provides the opportunity for accidental mouse transportation. If the rate of mouse 
transport between the mainland and Waikawa Island is high, then population samples from each will be genetically similar. If there is little or no successful dispersal, we expect to detect lower levels of genetic diversity within the island population and potentially genetic differentiation from the mainland population. Therefore, the genetic structure will provide information about current mouse movement and degree of isolation, and inform the viability of long-term mouse eradication.

\section{Materials and methods}

Six locations in Hawkes Bay and Gisborne provided a total of 61 mice (Table 1; Fig. 1). Dead mice from the mainland were donated by members of the public during summer
2014/15 across four locations (Napier, Mahia, Wairoa and Gisborne) and these were subsampled to include mice from different properties (average of 3.3 properties per location). The fifth location was Onenui, the farm where sheep are moved between Waikawa Island and the mainland. Finally on Waikawa Island, 14 mice were caught and killed in traps (snap trap 'The Better Mouse Trap', Intruder Inc) over two nights during March 2015, in collaboration with DOC and in accordance with ethics approval from Massey University (Protocol 15/17). Mice were caught at three separate sites on Waikawa Island (up to $1.8 \mathrm{~km}$ apart) to increase the potential genetic diversity contained in our sample. Juvenile rats were separated from mice by phenotype (long tails relative to their body length and pale colour of the fur on their bellies) and species identity was confirmed with mtDNA sequence data.

Table 1. Haplotype diversity (1187 bp of mtDNA D-loop and flanking regions) in six population samples of mice, Mus musculus, and sample sizes used to study nuclear and morphological distinctiveness of the Waikawa Island population. $\mathrm{N}=$ sample size, $\mathrm{H}=$ haplotype diversity ( \pm standard deviation), $\pi=$ average nucleotide site diversity $( \pm$ standard deviation).

\begin{tabular}{|c|c|c|c|c|c|c|c|c|c|c|c|c|c|c|c|c|c|}
\hline Location & $\begin{array}{c}\text { N } \\
\text { mtDNA }\end{array}$ & $\begin{array}{c}\text { dom } \\
\text { NZ.3 }\end{array}$ & $\begin{array}{c}\text { dom } \\
\text { NZ.12 }\end{array}$ & $\begin{array}{c}\text { dom } \\
\text { NZ.14 }\end{array}$ & $\begin{array}{c}\text { dom } \\
\mathrm{NZ} .3 \mathrm{~b}\end{array}$ & $\begin{array}{c}\text { new } \\
\text { dom } \\
\text { NZ.24 }\end{array}$ & $\begin{array}{c}\text { new } \\
\text { dom } \\
\text { NZ.23 }\end{array}$ & $\begin{array}{c}\text { new } \\
\text { dom } \\
\text { NZ.25 }\end{array}$ & $\begin{array}{c}\text { new } \\
\text { dom } \\
\text { NZ.26 }\end{array}$ & $\begin{array}{l}\text { dom } \\
\text { NZ.1 }\end{array}$ & $\begin{array}{c}\text { new } \\
\text { dom } \\
\text { NZ.22 }\end{array}$ & $\begin{array}{c}\text { Haplo } \\
\text { number }\end{array}$ & $\mathbf{H}$ & SD & $\pi$ & SD & $\begin{array}{c}\mathrm{N} \\
\text { vkorc }\end{array}$ \\
\hline Onenui & 5 & 4 & & & & & & 1 & & & & 2 & 0.4000 & \pm 0.237 & 0.0064 & \pm 0.004 & 5 \\
\hline Mahia & 21 & 15 & 3 & 2 & & & & & & & 1 & 4 & 0.4810 & \pm 0.121 & 0.0057 & \pm 0.003 & 4 \\
\hline Gisborne & 5 & 3 & 2 & & & & & & & & & 2 & 0.6000 & \pm 0.175 & 0.0091 & \pm 0.006 & 5 \\
\hline Wairoa & 7 & 4 & & 2 & 1 & & & & & & & 3 & 0.6667 & \pm 0.160 & 0.0071 & \pm 0.004 & 5 \\
\hline Napier & 9 & 5 & & 2 & & & & & 1 & 1 & & 4 & 0.6944 & \pm 0.147 & 0.0078 & \pm 0.005 & 4 \\
\hline
\end{tabular}
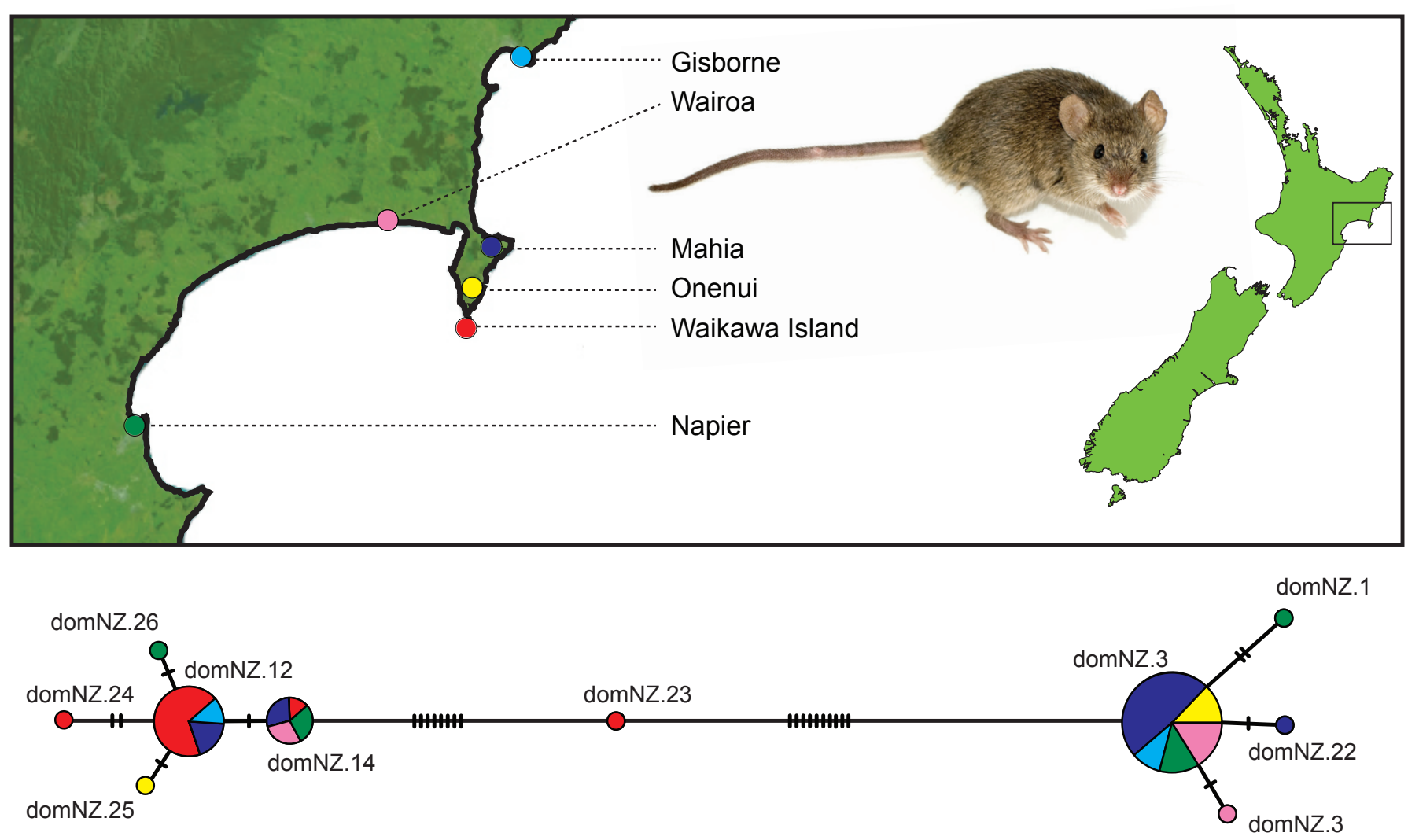

Figure 1. Genetic variation of house mouse Mus musculus from Waikawa Island and six population samples from adjacent mainland New Zealand locations. Haplotype network shows relationships of mtDNA (D-loop, $1187 \mathrm{bp}$ ) sequences with colours corresponding to sample location, and area proportional to sample size (Photo by George Shuklin/Wikimedia Commons). 


\begin{abstract}
Molecular analysis
Mouse DNA was used to amplify and sequence the complete mitochondrial D-loop and flanking regions (see Appendix S1 in Supplementary Materials for details). In addition, we amplified a nuclear gene, vitamin K 2,3-epoxide reductase subcomponent 1 (vkorc1; Song et al. 2011). Allelic variation at this locus is known to confer resistance to anticoagulant rodenticides such as warfarin (Rost et al. 2004; Song et al. 2011). Therefore, we sequenced one mouse from Waikawa Island from the beginning of exon 1 to the end of exon 2. To identify possible nuclear variation, we amplified and sequenced just exon 1 of $v$ korcl from a further 30 mice (Table 1). Data are available from http://evolves.massey.ac.nz/DNA_Toolkit.htm.

To visualise the relationship between the DNA sequences, haplotype networks were inferred using the minimum spanning approach (Bandelt et al. 1999) in PopART (Leigh \& Bryant 2015). To test for evidence of population differentiation we estimated pairwise $\Phi_{\mathrm{ST}}$ between each population using the software Arlequin 3.5 (Excoffier et al. 2005). If our mouse samples were taken from a single population, $\Phi_{\mathrm{ST}}$ would not differ from zero (Excoffier et al. 1992), therefore, we tested to see if pairwise $\Phi_{\mathrm{ST}}$ estimates were significantly $>0$ using 1000 permutations and, because of multiple pairwise tests, we used 0.0025 significance level.
\end{abstract}

\section{Morphological analysis}

New Zealand mice are the product of mixing at least three distinct lineages of Mus (European Mus musculus and M. domesticus, and Asian M. castaneus; Searle et al. 2009). These Mus lineages differ significantly in tail-length to body-length ratio (Kraft 1985) and this results in some local population differences in New Zealand (Searle et al. 2009). We measured tail and body length using the hanging-tail method (Jewell \& Fullagar 1966); each individual being suspended against a corkboard and pins placed in the board to mark the tip of the tail, the tip of the nose, and the base of the tail. Distances between pins were measured using a ruler. This process was repeated three times with each mouse and measurements averaged to reduce experimental error. We used a Wilcoxon-Mann-Whitney test to compare tail/body length ratios from island mice $(\mathrm{n}=10)$ and Mahia Peninsular mice (including Onenui; $\mathrm{n}=25$ ), and an ANOVA to compare all six population sample means simultaneously.

In many rodent species, island populations differ significantly in size from mainland relatives and populations without predators (Goldwater et al. 2012; Durst \& Roth 2015) and this trend has been documented in New Zealand mice (Russell 2012). Each mouse in our sample was weighed (balance accurate to $0.01 \mathrm{~g}$ ), and, because each population sample contained mice of different ages, we analysed morphological variation using an ANOVA-like Generalized Linear Model (GLM) fitted using the linear model ( $(\mathrm{m})$ function in the $\mathrm{R}$ statistical program, version 3.0.1. This approach allowed us to detect differences between quantitative predictors and qualitative factors as explanatory variables, and to construct an appropriate model incorporating variables with significant explanatory power. We used mouse weight as the response variable to determine whether collection location had any explanatory power in phenotype variation. We included as factors: tail length, body length, and collection location; and all interactions of these factors. When no significant interactions were detected we re-ran analyses without interactions.

\section{Results}

\section{Genetic structure}

We trimmed mtDNA D-loop sequences from 61 mice to align a 879 bp segment with 23 M. musculus domesticus haplotypes previously reported from New Zealand (King et al. 2016). All mouse mtDNA sequences observed in our study belong to the M. musculus domesticus haplogroup (see Figure S1 in Supplementary Material). Five haplotypes in our sample have already been reported in New Zealand mice (Genbank accessions: KP411761; KP411763; FM211632; FM211634; FM211635), but five D-loop sequences were new (Table 1).

The longer mtDNA sequences (1187 bp) from 61 mice were used for network inference and tests of population differentiation (see details in Appendix S1). Four haplotypes were detected in the Waikawa Island sample $(n=14)$. The common haplotype (domNZ.12; King et al. 2016) was also present in the Mahia and Gisborne samples, but two haplotypes were recorded only on Waikawa Island. Three haplotypes (domNZ.12; domNZ.14; domNZ.3) were widespread in Hawkes Bay (Fig. 1). In our data, the Gisborne sample had the highest nucleotide diversity $(\pi=0.0091)$ and Waikawa Island the lowest $\left(\pi=0.0015\right.$; Table 1). Estimates of pairwise $\Phi_{\mathrm{ST}}$ ranged from 0 to 0.74 (Table 2). Of the 15 population sample comparisons, only the five pairwise comparisons between Waikawa Island and mainland mice were significantly greater than zero, indicating significant genetic differentiation among these sampling locations (Table 2). Pairwise $\Phi_{\mathrm{ST}}$ between the Waikawa Island sample and the nearest populations at Mahia $\left(\Phi_{\mathrm{ST}}=0.497 ; \mathrm{P}<0.0001\right)$ and Onenui farm $\left(\Phi_{\mathrm{ST}}=0.603 ; \mathrm{P}<\right.$ 0.0001 ) suggested our samples represent separate populations.

The vitamin K 2,3-epoxide reductase subcomponent 1 (vkorcl) sequence from the single Waikawa mouse sampled was identical to published alleles found in German M. musculus domesticus (Genbank accession: GQ905715; GQ905714). This allele is not associated with resistance to anticoagulants (Song et al. 2011). All 30 mice from the Hawkes Bay region (Table 1) were homozygous for the same Exon 1 vkorcl allele.

\section{Morphological variation}

The largest mice were collected from Waikawa Island ( $>160$ $\mathrm{mm}$ total length; see Figure S2 in Supplementary Material). In Europe, mouse tail-length to body-length ratio is used to distinguish between subspecies M. musculus domesticus (1.014) and M. musculus musculus (0.872) (Kraft 1985). Variation in this trait is neither plastic nor age-dependent (Searle et al. 2009), and could potentially differentiate populations. In our study, mouse tail-length to body-length ratio averaged 0.961 (range 0.77-1.09) for all mainland mice measured (n $=46)$ and 1.01 (range 0.95-1.08) for Waikawa mice $(\mathrm{n}=10)$. Although the tail-length to body-length ratio of combined Mahia Peninsular mice $(\mathrm{n}=25)$ was significantly smaller than island mice (Wilcoxon-Mann-Whitney test; $P=0.028$ ), we did not detect significant differences among the population sample means for this ratio (ANOVA; $\mathrm{F}=1.56 ; P=0.201$; see Figure S2).

Waikawa Island produced the heaviest mice in our sample with a median weight twice that found at any other location (see Table S1 in Supplementary Material). The heaviest Waikawa mouse weighed $28.37 \mathrm{~g}$. Accommodating the variable contribution to samples of different mouse size (body length) we used a GLM with weight as the response variable. Mouse weights were influenced by both body length and location. 
Table 2. Genetic differentiation of population samples of mice from Waikawa Island and adjacent mainland New Zealand locations. Population pairwise $\Phi_{\mathrm{ST}}$ estimates based on $1187 \mathrm{bp}$ mtDNA (below diagonal). Pairwise $\Phi_{\mathrm{ST}}$ comparisons found to be significantly greater than zero $(\mathrm{P}<0.001)$ are indicated by $+($ above diagonal).

\begin{tabular}{lcccccc}
\hline & Waikawa & Onenui & Mahia & Gisborne & Wairoa & Napier \\
\hline Waikawa & & + & + & + & + & + \\
Onenui & 0.6030 & & - & - & - & - \\
Mahia & 0.4968 & -0.0408 & & - & - & - \\
Gisborne & 0.3127 & 0.0385 & -0.0346 & & - & - \\
Wairoa & 0.4880 & 0.0020 & 0.0000 & 0.0328 & & -0.0999 \\
Napier & 0.4664 & -0.0099 & 0.0025 & 0.0220 & \\
\hline
\end{tabular}

Mice from Waikawa Island were significantly heavier even when body length was accounted for $(P=0.0118$; see Table S2 in Supplementary Material). Weight is a plastic trait and variation could be due to reduced predation rates leading to longer lifespans, pregnancy, or better nutrition. Although these factors are all environmental effects, they have previously been detected in isolated island populations of mice (Russell 2012).

\section{Discussion}

Ten different mtDNA haplotypes were found in a sample of 61 mice, but only four of these were present in our sample from Waikawa Island. The presence of four haplotypes indicates that at least four different females have arrived and successfully bred. Two Waikawa haplotypes were also observed on the mainland at Mahia Peninsula, but not at Onenui, which is the most likely source of new mice because sheep are regularly moved between the farm and the island. All population samples included unique haplotypes, yet they also shared haplotypes with other populations. Multiple invasion events increase genetic diversity (Jones et al. 2011; Nathan et al. 2015), but the nucleotide diversity of the Waikawa Island sample was lower than all other samples. In addition, the Waikawa Island mouse population sample was significantly genetically differentiated from the nearest mainland populations on Mahia Peninsula. If our samples are representative of the populations then this suggests that mice are not successfully dispersing to the island frequently. No allelic variation was detected at the nuclear locus vkorc1. Although this locus is involved in resistance to anticoagulant rodenticides in some mouse populations, it is likely to be under constraining selection in the absence of rodenticides (Rost et al. 2004).

Waikawa Island mice have longer tails in relation to body length and the population, sampled at the same time of year, had larger individuals than the mainland mouse population. Island mice are often larger than their mainland counterparts, possibly due to reduced predator numbers (Berry et al. 1978). Relatively low predation rates could increase the average age of mice, or extend their breeding season. Such differences have an environmental not genetic basis, but provide further evidence that Waikawa Island contains a population with insular ecology.

Waikawa Island is an important breeding location for an endangered bird, the New Zealand shore plover. Mice on the island hamper the discovery, location and removal of rats when they arrive. In addition, the likelihood that mice are a direct threat to some island bird populations (Russell 2012; Wanless et al.2012) suggests native wildlife would benefit from the eradication of mice. The Waikawa Island mice examined in this study were morphologically and genetically distinct from those sampled on the adjacent mainland. Although the mitochondrial diversity on the island suggests at least four females have arrived at some time in the past, gene flow does not appear to be on-going. If mice arrive infrequently, an eradication effort could be successful and have long-term benefits as current best practice involves the deployment of bait and traps to monitor rodent reinvasion (O'Connor \& Eason 2000). However, vacant habitat could be susceptible to increased colonisation success (Russell et al. 2010; Waters et al. 2013; Fraser et al. 2015). Although the genetic diversity data indicate limited gene flow, it is possible that migrant mice currently reach the island but fail to contribute to the current population. Eradication of the mice of Waikawa Island would be one way to test this possibility (Hardouin et al. 2010; Buckley et al. 2013; Waters et al. 2013). The absence of mice, even for a single breeding season, would aid discovery of rats that can swim to Waikawa Island and thus reduce the risk of local extinction of shore plovers. Failure to detect alleles that confer resistance to anticoagulant rodenticides (such as warfarin) in the Waikawa Island mouse population increases support for successful eradication of this invasive species.

\section{Acknowledgements}

Our thanks to all those who donated mice, and to Tawapata South Incorporated for allowing trapping of mice on Waikawa Island. Vaughan Symonds and members of the Phoenix lab (Evolves.massey.ac.nz) provided useful comments. Louisa Sivyer helped with molecular diversity indices, Ian Henderson provided statistical advice, Doug Armstrong and Isobel Castro provided helpful suggestions for the ethics application, Simone Rost provided vkorcl primer sequences, Keith Broome provided technical advice on the likelihood of rat reinvasion, and Helen Jonas asked the original research question and provided support and advice. Ethics approval (Protocol 15/17) granted by Massey University. We thank the reviewers and editors who provided helpful comments on earlier versions of this manuscript.

\section{References}

Avise JC 2000. Phylogeography: the history and formation of species. Cambridge, MA, Harvard University. 447 p.

Bandelt H, Forster P, Röhl A 1999. Median-joining networks for inferring intraspecific phylogenies. Molecular Biology and Evolution 16: 37-48. 
Berry RJ, Peters J, Vanaarde RJ 1978. Sub-Antarctic house mice - colonization, survival and selection. Journal of Zoology 184: 127-141.

Bloomquist EW, Lemey P, Suchard MA 2010. Three roads diverged? Routes to phylogeographic inference. Trends in Ecology \& Evolution 25: 626-632.

Buckley HL, Paterson AM, Cruickshank RH 2013. The founder space race: a response to Waters et al. Trends in Ecology \& Evolution 28: 189-190.

Charlesworth B 2009. Effective population size and patterns of molecular evolution and variation. Nature Reviews Genetics 10: 195-205.

Dowding JE, O'ConnorSM2013. Reducing the risk of extinction of a globally threatened shorebird: translocations of the New Zealand shore plover (Thinornis novaeseelandiae), 1990-2012. Notornis 60: 70-84.

Durst AP, Roth VL 2015. Mainland size variation informs predictive models of exceptional insular body size change in rodents. Proceedings Royal Society B 282: 20150239.

Excoffier L, Smouse PE, Quattro JM 1992. Analysis of molecular variance inferred from metric distances among DNA haplotypes - application to human mitochondrialDNA restriction data. Genetics 131: 479-491.

Excoffier L, Laval G, Schneider S 2005. Arlequin (version 3.0): an integrated software package for population genetics data analysis. Evolutionary Bioinformatics 1: 47-50.

Excoffier L, Foll M, Petit RJ 2009. Genetic consequences of range expansions. Annual Review of Ecology Evolution and Systematics 40: 481-501.

Fraser CI, Banks SC, Waters JM 2015. Priority effects can lead to underestimation of dispersal and invasion potential. Biological Invasions 17: 1-8.

Goldwater N, Perry GLW, Clout MN 2012. Responses of house mice to the removal of mammalian predators and competitors. Austral Ecology 37: 971-979.

Hardouin EA, Chapuis JL, Stevens MI, van Vuuren JB, Quillfeldt P, Scavetta RJ, Teschke M, Tautz D 2010. House mouse colonization patterns on the sub-Antarctic Kerguelen Archipelago suggest singular primary invasions and resilience against re-invasion. BMC Evolutionary Biology 10: 325.

Jewell PA, Fullagar PJ 1966. Body measurements of small mammals - sources of error and anatomical changes. Journal of Zoology 150: 501-509.

Jones EP, Jensen JK, Magnussen E, Gregersen N, Hansen HS, Searle JB 2011. A molecular characterization of the charismatic Faroe house mouse. Biological Journal of the Linnean Society 102: 471-482.

King C, Alexander A, Chubb T, Carsons R, MacKay J, McCormick H, Murphy E, Veale A, Zhang H 2016. What can the geographic distribution of mtDNA haplotypes tell us about the invasion of New Zealand by house mice Mus musculus? Biological Invasions 18: 1551-1565.

Kraft R 1985. Morphological characteristics and distribution of the house mouse Mus musculus musculus L., 1758, and Mus musculus domesticus Rutty, 1772 (Rodentia, Muridae) in Bavaria. Säugetierk. Mitt 32: 1-12.

Leigh JW, Bryant D 2015. POPART: full-feature software for haplotype network construction. Methods in Ecology and Evolution 6: 1110-1116.

Lowe A, Harris S, Ashton P 2004. Ecological genetics: design, analysis, and application. Wiley-Blackwell. 344 p.

MacKay JWB, Alexander A, Hauber ME, Murphy EC, Clout MN 2013. Does genetic variation among invasive house mice in New Zealand affect eradication success? New
Zealand Journal of Ecology 37: 18-25

Nathan HW, Clout MN, MacKay JWB, Murphy EC, Russell JC 2015. Experimental island invasion of house mice. Population Ecology 57: 363-371.

Newman DG 1994. Effects of a mouse, Mus musculus, eradication program and habitat change on lizard populations of Mana Island, New Zealand, with special reference to Mcgregor skink, Cyclodina macgregori. New Zealand Journal of Zoology 21: 443-456.

O'Connor CE, Eason CT 2000. Rodent baits and delivery systems for island protection. Science for Conservation 150 . Wellington, New Zealand, Department of Conservation. $25 \mathrm{p}$.

Robins JH, Miller SD, Russell JC, Harper GA, Fewster RM 2016. Where did the rats of Big South Cape Island come from? New Zealand Journal of Ecology 40: 229-234.

Rost S, Fregin A, Ivaskevicius V, Conzelmann E, Hortnagel K, Pelz HJ, Lappegard K, Seifried E, Scharrer I, Tuddenham EGD, MullerCR, Strom TM, Oldenburg J 2004. Mutations in VKORC1 cause warfarin resistance and multiple coagulation factor deficiency type 2 . Nature 427:537-541.

Russell JC 2012. Spatio-temporal patterns of introduced mice and invertebrates on Antipodes Island. Polar Biology 35: 1187-1195.

Russell JC, Beaven BM, MacKay JWB, Towns DR, Clout MN 2008. Testing island biosecurity systems for invasive rats. Wildlife Research 35: 215-221.

Russell JC, Miller SD, Harper GA, McInnes HE, Wylie MJ, Fewster RM 2010. Survivors or reinvaders? Using genetic assignment to identify invasive pests following eradication. Biological Invasions 12: 1747.

Sakai AK, Allendorf FW, Holt JS, Lodge DM, Molofsky J, With KA, Baughman S, Cabin RJ, Cohen JE, Ellstrand NC, McCauley DE, O’Neil P, Parker IM, Thompson JN, Weller SG 2001. The population biology of invasive species. Annual Review of Ecology and Systematics 32: 305-332.

Searle JB, Jamieson PM, Gunduz I, Stevens MI, Jones EP, Gemmill CEC, King CM 2009. The diverse origins of New Zealand house mice. Proceedings of the Royal Society B Biological Sciences 276: 209-217.

Slatkin M 1987. Gene flow and the geographic structure of natural populations. Science 236: 787-792.

Song Y, Endepols S, Klemann N, Richter D, Matuschka FR, Shih CH, Nachman MW, Kohn MH 2011. Adaptive introgression of anticoagulant rodent poison resistance by hybridization between old world mice. Current Biology 21: 1296-1301.

Tabak MA, Poncet S, Passfield K, Martinez del Rio C 2015. Modeling the distribution of Norway rats (Rattus norvegicus) on offshore islands in the Falkland Islands. NeoBiota 24: 33-48.

Wanless RM, Ratcliffe N, Angel A, Bowie BC, Cita K, Hilton GM, Kritzinger P, Ryan PG, Slabber M 2012. Predation of Atlantic petrel chicks by house mice on Gough Island. Animal Conservation 15: 472-479.

Waters JM, Fraser CI, Hewitt GM 2013. Founder takes all: density-dependent processes structure biodiversity. Trends in Ecology and Evolution 28: 78-85.

Wedding CJ 2007. Aspects of the impacts of mouse (Mus musculus) control on skinks in Auckland, New Zealand. Unpublished MSc thesis, Massey University, Auckland. $133 \mathrm{p}$.

Editorial board member: Matt McGlone

Received 11 May 2016; accepted 6 December 2016 


\section{Supplementary Material}

Additional supporting information may be found in the online version of this article:

Appendix S1. Supplementary methods and molecular analysis. Figure S1. Network of Mus musculus domesticus mtDNA haplotypes sampled in New Zealand.

Figure S2. Variation in the ratio of tail-length to body-length in M. musculus from Waikawa Island and adjacent mainland New Zealand locations.

Table S1. Summary statistics for three body variables from six population samples of mice collected from Hawkes Bay, New Zealand.

Table S2. A linear model to explain weight variation (response variable) of mice collected from six locations in Hawkes Bay, New Zealand.

The New Zealand Journal of Ecology provides online supporting information supplied by the authors where this may assist readers. Such materials are peer-reviewed and copy-edited but any issues relating to this information (other than missing files) should be addressed to the authors. 